\title{
Enrich waste activated sludge digestibility via natural enzyme supplementation
}

\author{
Mohamed Elsamadony ${ }^{1}$ \\ Public Works Engineering Department, Faculty of Engineering, Tanta University, 31521 Tanta City, Egypt
}

\begin{abstract}
Upgrading of low biodegradable waste activated sludge (WAS) accomplished through supplement the hydrolysis step with natural enzymes source. Whereas, WAS is rich in particulate fractions in terms of total chemical oxygen demand (tCOD), total suspended solids (TSS) and volatile suspended solids (VSS) of $15.78,14.92$ and $12.15 \mathrm{~g} / \mathrm{L}$, respectively. Therefore, carica papaya enzymes were utilized to break down the peptide ponds in protein molecules such as papain and protease, as well as, lipases that catalyzed the degradation of lipids. The optimum mixture between papain, protease, and lipase enzymes was found to be 3: 1: 2 while the optimum enzyme concentration was $8 \%$. This conditions was attributed to enhance the $\mathrm{H}_{2}$ productivity form WAS by $97.8 \%$
\end{abstract}

\section{Introduction}

Large amount of wastewater generated daily from municipal and industrial activities which requires a proper treatment through physical and biological process. In this concern, abundant waste activated sludge (WAS) accumulates from secondary sedimentation tank located at wastewater treatment plants [1-3]. The classical technologies for stabilizing and managing this waste amounted about 40 to $60 \%$ of the operational cost, because the complex structure of particulate organic fractions originated at WAS [4]. Anaerobic digestion (AD) process represents an interesting choice to get rid of such a waste with add value in term of renewable energy source [5-8]. Whereas, AD has the ability to convert organic waste to energy carrier gases i.e. hydrogen and methane gases [9-14].

However, WAS is rich with protein and lipids fractions which that forms about $80 \%$ of the particulate organic fractions [15]. Therefore, pretreatment methods were applied on WAS prior to introduce to $\mathrm{AD}$ process to increase its solubility and make it easy to anaerobes to feed on [6]. One of the most common methods is the enzymatic hydrolysis, since it has the ability to reduce the lag phase, enhance the WAS digestibility and improve the liberation of extracellular polymeric substances (EPS) [16]. This is because enzymes such as amylase, protease and lipase degrade the complex polymeric substance and facilitate its transportation to subsequent acidogenesis microorganisms [17]. Protease and lipase producing microorganisms such as Bacillus sp. and Acinetobacter calcoaceticus, respectively revealed a decline of lipid concentration by $99 \%$ after twelve days when treating lipid rich wastewater under aerobic condition [18]. Moreover, the supplementation by lytic enzymes exhibited a COD degradation of $87 \%$ of pot ale residues via AD process. This was not the case when no enzymes were added, since only $13 \%$ were achieved [19].

On the other hand, commercial enzymes are too expensive which obstacle the practical application of the enzyme use at WAS pretreatment. Therefore, the aim of this study was to explore the availability of using a nature source to extract essential enzymes for WAS solubility such as papain, protease and lipase enzymes. This was accomplished by using Carica papaya plants. Furthermore, single and combined effect of the extracted enzymes on WAS hydrolysis were assessed. In addition, the concentration of the optimum enzymes mixture was tested and the maximum hydrogen potential was evaluated.

\section{Material and methods}

\footnotetext{
${ }^{1}$ Corresponding author: mohamed.elsamadony@,f-eng.tanta.edu.eg
} 


\subsection{Waste activated sludge and enzymes extracted}

Waste activated sludge (WAS) was collected from wastewater treatment plant located at Tanta city from the secondary sedimentation tank. The characteristics of the used WAS were as follows: $\mathrm{pH}$, tCOD, sCOD, TSS and VSS equal to 6.82, 15.78, 0.93, 14.92 and $12.15 \mathrm{~g} / \mathrm{L}$, respectively. Papain (Pn), protease $(\mathrm{Pt})$ and lipase $(\mathrm{Lp})$ enzymes were extracted from the latex and peels according to methods explained earlier at the following [20-22].

\subsection{Experimental setup}

Three batch assays were carried out to estimate sing and mixed enzymes on WAS hydrolysis, as well as, determining the optimum concentration of the ideal mixture. $100 \mathrm{~mL}$ WAS were loaded to $250 \mathrm{~mL}$ serum bottles then loaded with enzymes according to procedure listed at Table 1. Afterwards, the bottles were purged with $\mathrm{N}_{2}$ gas to maintain anaerobic condition at cultivated at mesophilic condition $\left(35^{\circ} \mathrm{C}\right)$.

Table 1.

Batch anaerobic experiments of single and mixed enzymes effect.

\begin{tabular}{|c|c|c|}
\hline Exp. 1: Single enzyme effect & $\begin{array}{l}\text { Exp. 2: Mixed-enzymes effect } \\
\text { with fixed concentration } 3 \% \\
(\mathrm{w} / \mathrm{w})\end{array}$ & $\begin{array}{l}\text { Exp. 3: Effect of enzymes } \\
\text { mixture of Pn : Pt: Lp }(2: 1: 3) \\
\text { concentrations }\end{array}$ \\
\hline No enzyme addition & Pn : Pt: Lp $(2: 1: 1)$ & $1 \%(\mathrm{w} / \mathrm{w})$ \\
\hline 3\%(w/w) Pn & Pn : Pt: Lp $(1: 2: 1)$ & $2 \%(\mathrm{w} / \mathrm{w})$ \\
\hline $3 \%(\mathrm{w} / \mathrm{w}) \mathrm{Pt}$ & Pn : Pt: Lp $(1: 1: 2)$ & $4 \%(w / w)$ \\
\hline \multirow[t]{6}{*}{$3 \%(w / w) L p$} & Pn : Pt: Lp $(3: 1: 1)$ & $6 \%(w / w)$ \\
\hline & Pn : Pt: Lp $(1: 3: 1)$ & $8 \%(w / w)$ \\
\hline & Pn : Pt: Lp $(1: 1: 3)$ & $10 \%(\mathrm{w} / \mathrm{w})$ \\
\hline & Pn : Pt: Lp $(3: 2: 1)$ & $15 \%(\mathrm{w} / \mathrm{w})$ \\
\hline & Pn : Pt: Lp $(1: 3: 2)$ & $20 \%(\mathrm{w} / \mathrm{w})$ \\
\hline & Pn : Pt: Lp $(2: 1: 3)$ & \\
\hline
\end{tabular}

\subsection{Analytical methods}

Total suspended solids (TS), volatile suspended solids (VS) and chemical oxygen demand (COD were quantified according to APHA [28]. Cumulative biogas was amounted using displacement method. Besides, $\mathrm{H}_{2}$ content in the eveloved biogas was determined by a gas chromatograph (GC) using method mentioned at [10].

\subsection{Solubilization efficiency (\%) and Hydrolysis coefficient}

Solubilization efficiency of $\mathrm{COD}_{\mathrm{t}}$ was obtained to assess the enzymatic hydrolysis effect. The COD solublization was calculated using the following equation, where, $\alpha$ is solubilization efficiency (\%)

$$
\alpha=\frac{\text { Hydrolyzed } \mathrm{COD}_{\mathrm{s}}-\text { Influent }_{\mathrm{COD}}}{\text { Influent } \mathrm{COD}_{\mathrm{t}}-\text { Influent } \mathrm{COD}_{\mathrm{s}}}
$$

Hydrolysis of organic polymers is often described by a first-order kinetic model, Where, $\mathrm{K}_{\mathrm{h}}$ is the solubilisation rate constant

$$
\begin{aligned}
& -\frac{d X}{d t}=K_{h} \cdot X \\
& \ln X=-K_{h} \cdot t+b
\end{aligned}
$$

\section{Results and discussions}

\subsection{Single enzyme effect on WAS solubility}


Fig. 1a and b revealed the effect single effect of each enzyme type on the WAS solublization efficiency. The maximum solubilization efficiency of $27.6 \%$ was recorded when papain enzyme was supplemented with concentration of $3 \%$ followed by lipase and protease enzymes with percentages of 18.5 and $13.6 \%$, respectively. This is because papain is a strong protein enzyme degrader and more than $60 \%$ WAS's organic content is complex protein fraction; therefore, papain enzyme achieved the maximum solublization efficiency [17].

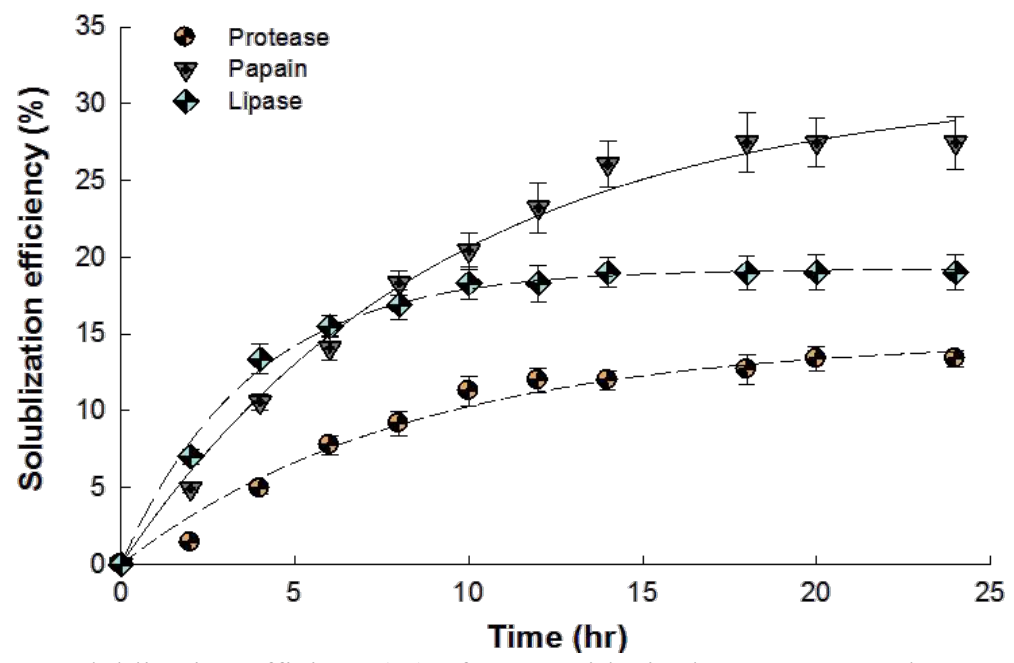

Fig. 1. Solublization efficieny (\%) of WAS with single enzyme supplementation.

\subsection{Mixed Enzymes effect on WAS solubility}

In order to evaluate the synergistic effect of mixed enzymes supplementation, different mixtures of the three enzymes were examined. The optimum mixture was papain: protease: lipase enzymes ratios of $3: 1: 2$. This mixture registered the highest solubilzation efficiency and hydrolysis rate constant of $47.2 \%$ and $-0.03 \mathrm{~h}^{-1}$, respectively. The synergistic effect between different enzymes were previously emphasized by Yang et al. [24], since they discovered that a significant reduction at VSS content was recorded when use a mixture $1: 3$ of amylase to protease exceeded the single effect of each of them.

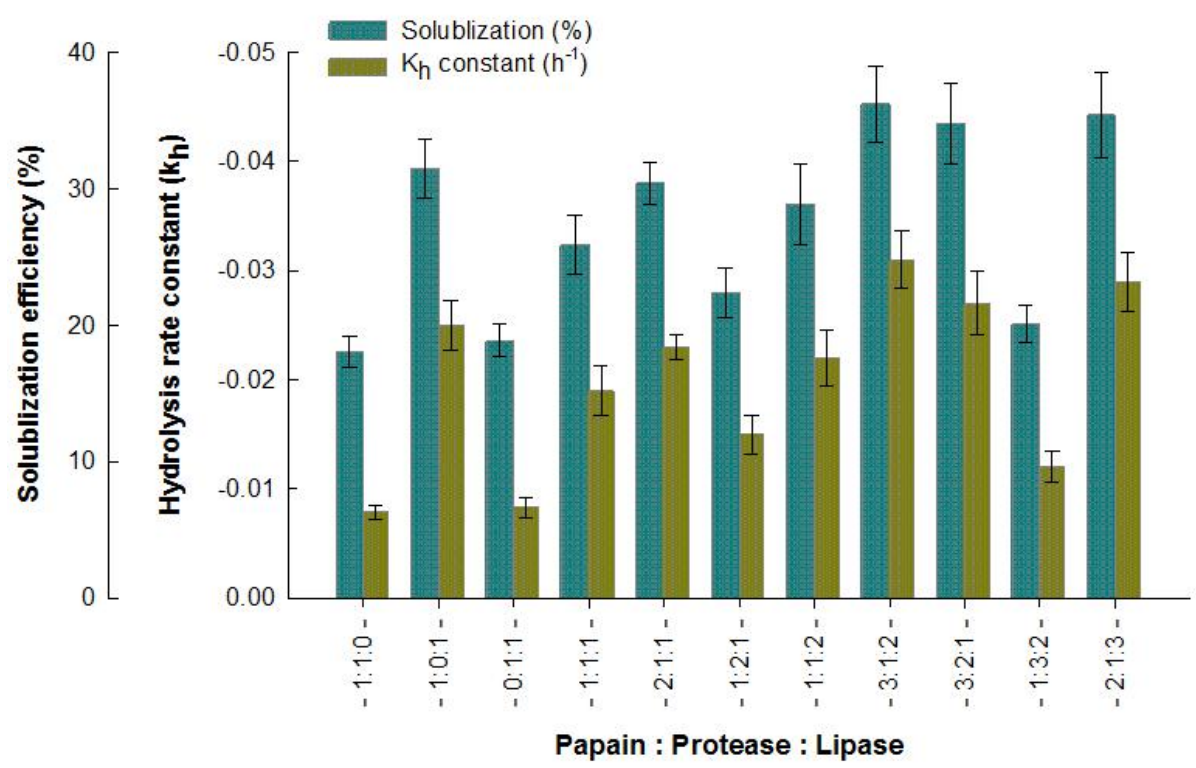

Fig. 2. Solublization efficieny (\%) and hydrolysis rate constant of WAS under mixed enzyme supplementation. 


\subsection{Effect of enzyme concentration on WAS digestibility and $\mathrm{H}_{2}$ productivity}

Solublization efficiency found to be enzyme concentration dependent as explored from Fig. 3 . However, after certain concentration a slight increase at solublization efficiency occurred. Similarly, hydrolysis rate constant were achieved the same trend. Maximum solublization efficiency was $52.6 \%$ at enzymes concentration of $20 \%$, however, at concentration of $10 \%$ solublization efficiency was $47.9 \%$. This means that with doubling the concentration, the solublization efficiency only incremented by $4.7 \%$. On the other hand, $\mathrm{H}_{2}$ potential were evaluated at different enzyme concentration, maximum $\mathrm{H}_{2}$ productivity of $452.1 \mathrm{~mL}$ were noticed at enzyme concentration of $8 \%$ compared with only $228.6 \mathrm{~mL}$ at control batch (no enzymes were added). This is due to increasing the solubility of WAS structure, as well as, breaking down the complex compounds to simple compounds that anaerobes able to feed on and convert them into hydrogen. However, further enzyme concentration augmentation led to a reduction at $\mathrm{H}_{2}$ productivity until reached $179.2 \mathrm{~mL}$ at concentration of $20 \%$. This may as a result of enzymes is originally a protein molecule so at certain limit hinder the process, as well as, further dissolution of organics to tiny structure can penetrate the bacterial membrane and kill the anaerobes [16, $25]$.

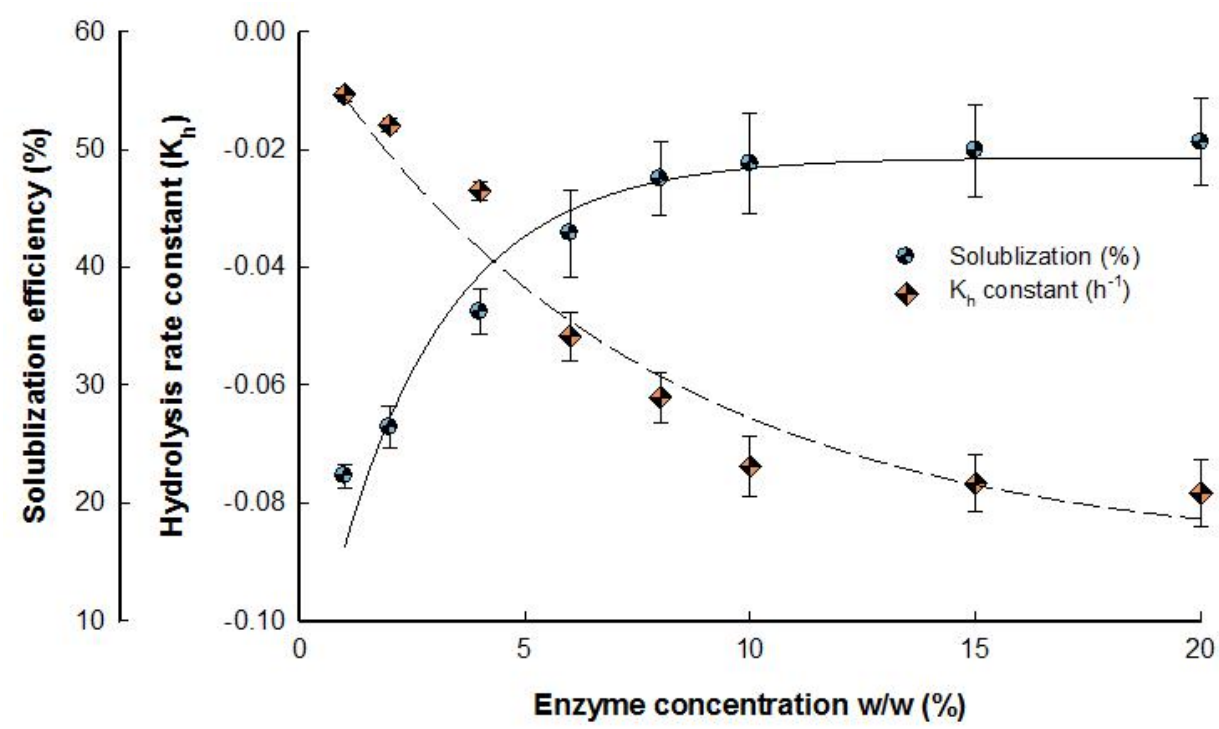

Fig. 3. Solublization efficieny (\%) and hydrolysis rate constant of WAS versus enzymes concentration.

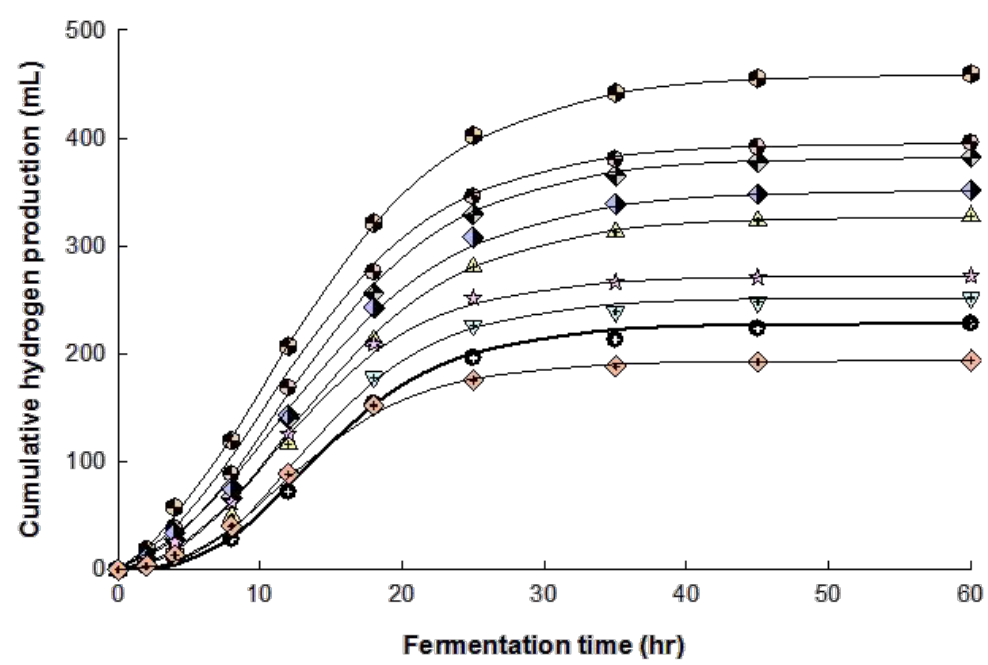

- Control

$\nabla 1(w / w) \%$

A. $2(w / w) \%$

$4(w / w) \%$

$6(w / w) \%$

$8(w / w) \%$

- $10(w / w) \%$

th $15(w / w) \%$

$\hookrightarrow \quad 20(w / w) \%$

Fig. 4. Hydrogen potential harvested from WAS at different enzymes concentration.

\section{Conclusions}


Enzymes supplementation found to be an optimistic approach to enhance WAS solubility and improve hydrogen potential. Papain was the most effective enzyme, however, synergistic effect was found between the three tested enzymes with optimum ratio of papain: protease: lipase equal to $3: 1: 2$. Moreover, the optimum enzyme mixture concentration was $8 \%$ which achieved the highest hydrogen potential of $452.1 \mathrm{~mL}$.

\section{References}

1. Mostafa, A., Elsamadony, M., El-Dissouky, A., Elhusseiny, A., Tawfik, A.: Biological H2potential harvested from complex gelatinaceous wastewater via attached versus suspended growth culture anaerobes. Bioresour. Technol. 231, 9-18 (2017).

2. Elsheikh, M.A., Saleh, H.I., Rashwan, I.M., El-Samadoni, M.M.: Hydraulic modelling of water supply distribution for improving its quantity and quality. Sustain. Environ. Resour. 23, 403411 (2013).

3. Tawfik, A., Elsamadony, M.: Development of Dry Anaerobic Technologies of Bio-waste and Unlock the Barriers for Valorization. In: Purohit, H.J., Kalia, V.C., Vaidya, A.N., and Khardenavis, A.A. (eds.) Optimization and Applicability of Bioprocesses. pp. 267-282. Springer Singapore, Singapore (2017).

4. Zhang, B., He, P. jing, L??, F., Shao, L. ming, Wang, P.: Extracellular enzyme activities during regulated hydrolysis of high-solid organic wastes. Water Res. 41, 4468-4478 (2007).

5. Farghaly, A., Elsamadony, M., Ookawara, S., Tawfik, A.: Bioethanol production from paperboard mill sludge using acid-catalyzed bio-derived choline acetate ionic liquid pretreatment followed by fermentation process. Energy Convers. Manag. 145, 255-264 (2017).

6. Elsamadony, M., Tawfik, A.: Maximization of hydrogen fermentative process from delignified water hyacinth using sodium chlorite. Energy Convers. Manag. 157, 257-265 (2018).

7. Ismail, S., Elsamadony, M., Elreedy, A., Fujii, M., Tawfik, A.: Physico-chemical and microbial characterization of compartment-wise profiles in an anammox baffled reactor. J. Environ. Manage. 232, 875-886 (2019).

8. Ismail, S., Elsamadony, M., Fujii, M., Tawfik, A.: Evaluation and optimization of anammox baffled reactor (AnBR) by artificial neural network modeling and economic analysis. Bioresour. Technol. 271, 500-506 (2019).

9. Wazeri, A., Elsamadony, M., Tawfik, A.: Carbon emissions reduction by catalyzing H2 gas harvested from water hyacinth fermentation process using metallic salts. Energy Procedia. 152, 1254-1259 (2018).

10. Soltan, M., Elsamadony, M., Tawfik, A.: Biological hydrogen promotion via integrated fermentation of complex agro-industrial wastes. Appl. Energy. 185, 929-938 (2017).

11. Elsamadony, M., Tawfik, A.: Dry anaerobic co-digestion of organic fraction of municipal waste with paperboard mill sludge and gelatin solid waste for enhancement of hydrogen production. Bioresour. Technol. 191, 157-165 (2015).

12. Elsamadony, M., Tawfik, A., Danial, A., Suzuki, M.: Optimization of hydrogen production from organic fraction of municipal solid waste ( OFMSW ) dry anaerobic digestion with analysis of microbial community. Int. J. Energy Res. 39, 929-940 (2015).

13. Elsamadony, M., Tawfik, A.: Potential of biohydrogen production from organic fraction of municipal solid waste (OFMSW) using pilot-scale dry anaerobic reactor. Bioresour. Technol. 196, 9-16 (2015).

14. Elsamadony, M., Tawfik, A., Suzuki, M.: Surfactant-enhanced biohydrogen production from organic fraction of municipal solid waste (OFMSW) via dry anaerobic digestion. Appl. Energy. 149, 272-282 (2015).

15. Wazeri, A., Elsamadony, M., Roux, S. Le, Peu, P., Tawfik, A.: Potentials of using mixed culture bacteria incorporated with sodium bicarbonate for hydrogen production from water hyacinth. Bioresour. Technol. 263, 365-374 (2018).

16. Donoso-Bravo, A., Fdz-Polanco, M.: Anaerobic co-digestion of sewage sludge and grease trap: Assessment of enzyme addition. Process Biochem. 48, 936-940 (2013).

17. Elsamadony, M., Tawfik, A., Danial, A., Suzuki, M.: Use of Carica Papaya Enzymes for Enhancement of H2 Production and Degradation of Glucose, Protein, and Lipids. Energy Procedia. 75, 975-980 (2015).

18. Mongkolthanaruk, W., Dharmsthiti, S.: Biodegradation of lipid-rich wastewater by a mixed bacterial consortium. Int. Biodeterior. Biodegradation. 50, 101-105 (2002).

19. Mallick, P., Akunna, J.C., Walker, G.M.: Anaerobic digestion of distillery spent wash: 
Influence of enzymatic pre-treatment of intact yeast cells. Bioresour. Technol. 101, 1681-5 (2010).

20. Nitsawang, S., Hatti-Kaul, R., Kanasawud, P.: Purification of papain from Carica papaya latex: Aqueous two-phase extraction versus two-step salt precipitation. Enzyme Microb. Technol. 39, 1103-1107 (2006).

21. Chaiwut, P., Pintathong, P., Rawdkuen, S.: Extraction and three-phase partitioning behavior of proteases from papaya peels. Process Biochem. 45, 1172-1175 (2010).

22. PAQUES, F., PIO, T., CARVALHO, P., MACEDO, G.: Characterization of the lipase from Carica papaya residues. Brazilian J. food Technol. 11, 20-27 (2008).

23. APHA: Standard Methods for the Examination of Water and Wastewater., Washington, DC, USA (2005).

24. Yang, Q., Luo, K., Li, X. ming, Wang, D. bo, Zheng, W., Zeng, G. ming, Liu, J. jin: Enhanced efficiency of biological excess sludge hydrolysis under anaerobic digestion by additional enzymes. Bioresour. Technol. 101, 2924-2930 (2010).

25. Romano, R.T., Zhang, R., Teter, S., McGarvey, J.A.: The effect of enzyme addition on anaerobic digestion of Jose Tall Wheat Grass. Bioresour. Technol. 100, 4564-4571 (2009). 